\title{
DIFFERENCE IN PERSONAL HYGIENE BETWEEN ELDERLY LIVING WITH FAMILY AND THOSE LIVING IN NURSING HOME, PARE, EAST JAVA
}

\author{
Prima Dewi Kusumawati \\ School of Health Sciences (STIKES) Surya Mitra Husada, Kediri
}

\begin{abstract}
BACKGROUND: Elderly experience physical infirmity, brain devolution, slow metabolic rate, slow cell replacement, which eventually have inadvertent impact on cognitive capability, emotional stability, and social interacttion. Living with family allows family members to interact with and assist the elderly in daily activities. In contrast, neither family members nor neighbors can interact socially with the elderly living in the nursing home. This study aimed to determine the difference in personal hygiene between elderly living with family and those living in nursing home.

SUBJECT AND METHODS: This was a cross-sectional study conducted in sub-district Kaliombo, Jombang, Pare, East Java. A sample of 40 elderly people was selected from the community in Kediri. Another sample of 40 elderly was selected from a UPT PSLU Jombang Nursing Home, Pare, East Java. The dependent variable was personal hygiene. The independent variable was the elderly residence. The data on personal hygiene was obtained by a questionnaire. The difference in personal hygiene between the 2 groups was tested by Fisher exact chi square test.

RESULTS: Elderly living with family had better personal hygiene than those living in the nursing home, and it was statistically significant $(\mathrm{p}=0.019)$. Among the elderly living with family, $15(75 \%)$ had good, 3 (15\%) had fair, and 2 (10\%) had poor personal hygiene. Among the elderly living in the nursing home, 5 (25\%) had good, 8 (40\%) had fair, and 7 (35\%) had poor personal hygiene.

CONCLUSION: Elderly living with family have better personal hygiene than those living in the nursing home. Families should extend their care to their older members in older to maintain their personal hygiene.
\end{abstract}

Keywords: personal hygiene, elderly, living with family, nursing home 